\title{
Evaluation of Antioxidant, Antiglycant and ACE-Inhibitory Activity in Enzymatic Hydrolysates of $\alpha$-Lactalbumin
}

\author{
Adriana Maite Fernández-Fernández, Tomás López-Pedemonte, Alejandra Medrano-Fernandez ${ }^{*}$ \\ Departamento de Ciencia y Tecnología de Alimentos, Facultad de Química, Universidad de la República, \\ Montevideo, Uruguay \\ Email: *amedrano@fq.edu.uy
}

How to cite this paper: Fernández-Fernández, A.M., López-Pedemonte, T. and Medrano-Fernandez, A. (2017) Evaluation of Antioxidant, Antiglycant and ACE-Inhibitory Activity in Enzymatic Hydrolysates of $\alpha$-Lactalbumin. Food and Nutrition Sciences, 8, 84-98.

http://dx.doi.org/10.4236/fns.2017.81006

Received: November 30, 2016

Accepted: January 10, 2017

Published: January 13, 2017

Copyright (C) 2017 by authors and Scientific Research Publishing Inc. This work is licensed under the Creative Commons Attribution International License (CC BY 4.0).

http://creativecommons.org/licenses/by/4.0/

\begin{abstract}
Whey proteins are known for their high nutritional value and bioactivity, notably great potential is found on $\alpha$-lactalbumin. The objective of this study was to evaluate antioxidant, antiglycant and ACE (angiotensin converting enzyme)-inhibitory activity of $\alpha$-lactalbumin peptides obtained from enzymatic hydrolysis with Alcalase through different hydrolysis conditions. The optimization of enzymatic hydrolysis was studied by response surface methodology variating enzyme:substrate ratio $(0.0050 \%, 0.0525 \%$ and $0.1000 \% \mathrm{w} / \mathrm{w})$ and time (0, 30 and 60 minutes) measuring antioxidant activity by ABTS and ORAC-FL (response variables), founding an augment of this activity with time. Characterization of seven samples showed increasing hydrolysis with time. Hydrolysate obtained with $0.1000 \% \mathrm{w} / \mathrm{w}$ and 60 minutes demonstrated higher antioxidant activity related to greater hydrolysis. This hydrolysate did not show antiglycant activity but promoted advanced glycation end products formation with methylglyoxal and glucose. In contrast, this sample showed $30 \%$ of ACE inhibition when compared to Captopril, having great potential by enhancing hydrolysis.
\end{abstract}

\section{Keywords}

Whey Protein, Enzymatic Hydrolysis, Antioxidant, Antiglycant, ACE Inhibition

\section{Introduction}

Milk whey proteins are low cost by-products of the cheese making industry known for their high nutritional value. Whey stands for a $90 \%$ of bovine milk containing $80 \%$ of caseins and $20 \%$ of whey proteins respected to total milk protein content [1]. Whey proteins consist of two major proteins: $\beta$-lactoglobulin ( $58 \% \mathrm{w} / \mathrm{w}$ of whey proteins) and $\alpha$-lactalbumin (20\% w/w of whey proteins) [2]. Cheese manufacture produces near 86 
million tonnes of whey proteins per year [3] having a big impact on the environment and representing a huge waste of proteins with high potential uses.

Food industry has invested in the revalorization of its effluents to create added-value products by investigating their biologically beneficial properties [4]. $\alpha$-lactalbumin is the second major protein of whey proteins which has a globular structure with 123 residues and two subdomains ( $\alpha$ with 4 -helices and $\beta$ with $\beta$-sheets and loop regions) [5]; [6], a molecular weight of $14-17 \mathrm{kDa}$ and an isoelectric point of 4.2 [6], four disulfide bonds and a calcium ion [7]. In the primary structure of these protein tryptophan, leucine and cysteine can be found and these residues could be the responsible ones for great antioxidant properties. $\alpha$-lactalbumin has 8 cysteines which stabilize its tertiary structure through disulfide bonds [8]. $\alpha$-lactalbumin has a great amount of essential amino acids [8], most of which could confer bioactive properties by being released as peptides after enzymatic hydrolysis [8] [9]. These bioactive properties would be antioxidant, antiglycant and antihypertensive, among others [9].

Antioxidants are compounds which neutralize oxygen and nitrogen reactive species produced by cells in oxidative stress conditions [10]. Oxidative stress is caused by normal cellular metabolism of aerobic organisms in which these species are generated, including free radicals (atoms, group of atoms or molecules which at least have one unpaired electron) [11], in a higher quantity than what the cell can overcome by its endogen mechanisms (superoxide dismutase, catalase and glutathione peroxidase) [10]; [12]. Glutathione is a non proteic molecule of 3 residues which takes part in endogen response to oxidative stress to prevent chronic diseases. Oxygen reactive species and oxidative stress are involved in chronic diseases such as cancer, diabetes, ischemia, cardiovascular diseases, infection, Parkinsonism, atherosclerosis and arthritis, among others [10] [13]. Sadat et al. [14] studied antioxidant activity of the peptides obtained from the hydrolysis of $\alpha$-lactalbumin with termolysine, being able to isolate and identify the peptides responsible for these activity; residues of major activity were tryptophan and tyrosine positioned at the end of different peptides. $\alpha$-lactalbumin beholds more aromatic residues than $\beta$-lactoglobulin (whey protein in greater proportion) [15].

One major chronic disease is diabetes which consists of a hyperglycemia due to relative or absolute deficiency of insulin and/or resistance to it [16] [17]. Diabetes is the forth cause of death in developed countries and is an epidemic in a lot of developing ones. It is estimated that this disease affects $25 \%$ of world population [18]. Glycation is the major cause of spontaneous damage to proteins in physiologic systems being exacerbated in diabetes. Advanced glycation end products (AGEs) formation is reached by modification of N-terminus groups and residues such as lysine, cysteine and arginine [19] [20]. Protein glycation is produced by Maillard reaction (nonenzymatic browning reaction) which starts with the condensation between an amino group available and a carbonyl, in general, a reducing carbohydrate to form a Shiff base. These Shiff base suffers chemical rearrangements forming Amadori or early glycation products [21] [22] [23]. When these products accumulate crosslinked proteins can be formed [21]. AGEs can also be generated by glucose autooxidation and lipids peroxidation through oxidative stress, forming dicarbonyl derivatives ( $\alpha$-oxaldehides such as methylglyoxal (MGO), glyoxal and 3-deoxyglucosone) which can interact with monoacids to produce AGEs [21] [24] [25]. This would imply that the presence of antioxidants in foods could be re- 
lated to a reduction in AGEs formation (antiglycant activity) [24] [25] [26].

Another chronic disease is cardiovascular disease which is associated with hypertension (arterial blood pressure sustained elevation) and is of great incidence in developed countries [27]. The dipeptidyl carboxypeptidase ACE (angiotensin I-converting enzyme) regulates arterial pressure by the renin-angiotensin system for which ACE inhibition reduces arterial pressure by reducing the levels of angiotensin II (vasoconstrictor) and increasing bradykinin (vasodilator) [27]. Captopril and enalapril are reference drugs to treat hypertension but they have secondary effects for which foods could avoid [28]. Some authors have found antihypertensive properties in milk proteins [9] [29] enhancing ACE inhibition by enzymatic hydrolysis [15] [30] because of the formation of tripeptides.

In the case of $\alpha$-lactalbumin, it has not been thoroughly investigated in terms of obtaining powerful antioxidant peptides from enzymatic hydrolysis [14] as well as antiglycant and ACE-inhibitory activity.

Thus, the objective of this study was to evaluate the effect of different conditions of enzymatic hydrolysis (enzyme:susbstrate ratio and time of reaction) on antioxidant activity, using a response surface methodology (RSM), and hydrolysates characterization. In addition, ACE-inhibition and antiglycant activity were evaluated on the hydrolysate that presented the highest antioxidant activity.

\section{Materials and Methods}

\subsection{Materials}

Protein isolate of $\alpha$-lactalbumin (Biopure-lactoalbumin ${ }^{\mathrm{TM}}$ ) was provided by Davisco Food International Inc. (Le Sueur, MN, USA). Alcalase was from Novozymes Biopharma US Inc. Buffer salts were $\mathrm{NaHPO}_{4}$ (Mallinckrodt) and $\mathrm{NaH}_{2} \mathrm{PO}_{4}$ (J. T. Baker). Folin reagent and 1-anilin-8-naftensulfide (ANS) were purchased from Sigma Aldrich (St. Louis, MO). For electrophoresis analysis: acrylamide, bis-acrylamide, tricine, sodium dodecyl sulphate (SDS) and Tris were purchased from MP Biomedicals; 2-mercaptoethanol and the molecular weight marker (MWM) with 7 bands from 2.5 to 17 $\mathrm{kDa}$ (MW-SDS-17S) were purchased from Sigma Aldrich (St. Louis, MO); bromophenol blue (J. T. Baker), HCl (Dorwill), acetic acid (VETEC). For ABTS assays: 2,20- azinobis-(3-ethylbenzothiazoline-6-sulfonic acid) diammonium salt (ABTS) and 6-hydroxy-2,5,7,8-tetramethylchroman-2-acid (Trolox) were purchased from Sigma Aldrich, and potassium persulphate was from J. T. Baker. For ORAC (Oxygen Radical Antioxidant Capacity)-FL assay: Fluorescein (FL) disodium salt and 2,20-azobis (2methylpropionamidine) dihydrochloride (AAPH) were obtained from Sigma Aldrich (St. Louis, MO). For antiglycant assays: methylglyoxal (MGO) and aminoguanidine (AG) were purchased from Sigma Aldrich (St. Louis, MO); bovine serum albumin (BSA) (GIBCO BRL) and glucose (Glc) (Fluka). For angiotensin converting enzyme (ACE)-inhibition assay: histidil-hipuril-leucine (HHL) was purchased from Sigma Aldrich (St. Louis, MO).

\section{2. $\alpha$-Lactalbuminisolatehydrolysis}

The hydrolysis reaction was carried out using Alcalase enzyme with $8 \%(\mathrm{w} / \mathrm{V})$ of pro- 
tein isolate in buffer phosphate solution $100 \mathrm{mM} \mathrm{pH} 7$ and incubation temperature of water bath $30^{\circ} \mathrm{C}$ with agitation of $150 \mathrm{rpm}$. After incubation time (as in Section 2.3), reaction was stopped by heating at $100^{\circ} \mathrm{C}$ for 10 minutes. Samples were freezed, lyophilized and stored at $-20^{\circ} \mathrm{C}$ for subsequent analysis.

\subsection{Experimental Design}

For the optimization of hydrolysis process an experimental design [31] (compose central design) was used based on a response surface model, full factorial design. The hydrolysis reaction was evaluated by determining ABTS and ORAC-FL values (response variables) with the variation of two factors, enzyme:substrate ratio $(r)(\% \mathrm{w} / \mathrm{w})$ and time $(t)$ (minutes). Seven samples were prepared: four assays, two factors ( $r$ and $t$ ) with two levels $(0.0050$ and $0.1000 \% \mathrm{w} / \mathrm{w}, 0$ and 60 minutes, respectively) and three central points $(0.0525 \% \mathrm{w} / \mathrm{w}$ and 30 minutes, for $r$ and $t$ factors, respectively) in order to estimate the experimental error (sample conditions are listed in Table 1). The equation for the proposed model of response variables ABTS and ORAC-FL $\left(Y_{i}\right)$ is shown in Equation (1):

$$
Y_{i}=\beta_{0}+\beta_{1} r+\beta_{2} t+\beta_{1,2} r \times t+\varepsilon
$$

where $\beta_{0}$ is the intersection point; $\beta_{1}$ and $\beta_{2}$ are de linear coefficients; $\beta_{1,2}$ is the coefficient which represents the interaction between the independent variables (factors $r$ and $t$ ); and $\varepsilon$ is the variable error. Model parameters where calculated with Statgraphic Plus version 5.1 program by multiple linear regression (MLR).

\subsection{Characterization of $\alpha$-Lactalbumin Hydrolysates}

Protein content was determined by Lowry method [32] preparing $0.3 \mathrm{mg} / \mathrm{mL}$ solutions of each hydrolysate in phosphate buffer $10 \mathrm{mM} \mathrm{pH}=7.4$. Surface hydrophobicity was determined with the method described by Hayakawa and Nakai [33], based in spectrofluorimetry measurements with ANS (fluorescent probe). Hydrolysates solutions of $1 \mathrm{mg} / \mathrm{mL}$ were prepared in sodium phosphate buffer $100 \mathrm{mM} \mathrm{pH}=7.0$, agitated for 30 minutes at room temperature and centrifuged at $10.000 \mathrm{~g}$ and $4^{\circ} \mathrm{C}$ for 10 minutes. $8 \mathrm{mM}$

Table 1. Results of protein percentage, surface hydrophobicity and hydrolysis percentage of the $\alpha$-lactalbumin hydrolysates.

\begin{tabular}{|c|c|c|c|c|c|}
\hline \multirow{2}{*}{ Sample } & \multicolumn{2}{|c|}{ Factors } & \multirow{2}{*}{$\%$ Protein } & \multirow{2}{*}{ Surface hydrophobicity } & \multirow{2}{*}{ \% Hydrolysis } \\
\hline & $r$ & $t$ & & & \\
\hline 1 & 0.0050 & 0 & $86.7^{\mathrm{a}}$ & $0.1260^{\mathrm{b}}$ & $0^{\mathrm{a}}$ \\
\hline 2 & 0.1000 & 0 & $91.4^{\mathrm{a} . \mathrm{b}}$ & $0.1170^{\mathrm{b}}$ & $0^{\mathrm{a}}$ \\
\hline 3 & 0.0050 & 60 & - & - & - \\
\hline 4 & 0.1000 & 60 & $96.1^{\mathrm{b} . \mathrm{c}}$ & $0.0618^{\mathrm{a}}$ & $31^{\mathrm{c}}$ \\
\hline 5 & 0.0525 & 30 & $95.2^{b . c}$ & $0.2200^{c}$ & $22^{\mathrm{b}}$ \\
\hline 6 & 0.0525 & 30 & $96.1^{b . c}$ & $0.1180^{\mathrm{b}}$ & $23^{\mathrm{b}}$ \\
\hline 7 & 0.0525 & 30 & $97.3^{\mathrm{c}}$ & $0.1262^{\mathrm{b}}$ & $23^{\mathrm{b}}$ \\
\hline
\end{tabular}

Results are expressed as the means \pm SD $(n=6)$. ANOVA analysis was made by column using Tukey test. Means values in the same column with different letters $(a, b, c)$ state significant differences $(p<0.05)$. 
ANS solution was prepared weighting $0.00128 \mathrm{~g}$ of ANS in $5 \mathrm{~mL}$ of buffer. Measurements were made in spectrofluorimeter microplate reader (Varioskan ${ }^{\circledR}$ Flash, Thermo Electron Corporation) by adding $250 \mu \mathrm{L}$ of different concentration solutions and 3.75 $\mu \mathrm{L}$ of ANS in each well. Also, $250 \mu \mathrm{L}$ of $\mathrm{MeOH}$ and $3.75 \mu \mathrm{L}$ of ANS were added to determine maximum fluorescence. This probe was measured at $363 \mathrm{~nm}$ and $475 \mathrm{~nm}$ wave lengths of excitation and emission, respectively. According to Kato and Nakai [34] surface hydrophobicity index $\left(S_{0}\right)$ corresponds to the initial slope of the curve of probe's fluorescence intensity as a function of protein concentration. Equation (2) shows how to calculate surface hydrophobicity:

$$
I F=\frac{I F_{\text {protein+ANS }}-I F_{\text {protein }}}{I F_{\text {max imum }}}
$$

where $I F_{\text {protein+ANs }}$ is the protein's fluorescence intensity with ANS, $I F_{\text {protein }}$ is protein's fluorescence intensity without ANS, $I F_{\text {maximum }}$ is the maximum fluorescence which corresponds to methanol with ANS.

Tricine-SDS-PAGE analyses were performed for the hydrolysates according to the method described by Schägger and von Jagow [35]. Electrophoresis gel contains three parts: stacking, spacer and separating gels with $4 \%, 10 \%$ and $16 \%$ of acrylamide, respectively. Sample solutions were prepared of $2 \mathrm{mg} / \mathrm{mL}$ in sample buffer containing $12 \%$ glycerol, 4\% SDS, 2\% 2-mercaptoethanol (v/v), 50 mMTris, $0.01 \%$ bromophenol blue and $0.1 \mathrm{M} \mathrm{HCl}$ for $\mathrm{pH}$ adjustment. Cathodic buffer was prepared with $100 \mathrm{mMTris,}$ $0.1 \%$ SDS $(\mathrm{w} / \mathrm{V})$ and $100 \mathrm{mMTricine}, \mathrm{pH}$ 8.9. Anodic buffer was prepared with 200 mMTris and $0.1 \mathrm{M} \mathrm{HCl}$ for $\mathrm{pH}$ adjustment (pH 8.9). Electrophoresis conditions were as follows: $30 \mathrm{~V}$ and $30 \mathrm{~mA}$ until the front went through the stacking gel and then $90 \mathrm{~V}$ (Sigma Aldrich PS 250-2) for two gels of $1.0 \mathrm{~mm}$ thick. The apparatus used was an Amersham Biosciences SE 260. Gel fixation was performed by $50 \%$ methanol and $10 \%$ acetic acid solution during 30 minutes agitation and coloration was performed by a Coomasie Blue R250 0.1\% solution in 30\% methanol and 10\% acetic acid over night. Decoloration was performed by $30 \%$ methanol and $10 \%$ acetic acid solution during 30 minutes agitation and several washes with $15 \%$ methanol and $5 \%$ acetic acid solution. Molecular weight marker with 7 bands from 2.5 to $17 \mathrm{kDa}$ was used.

SE-HPLC analysis were carried out as described by Molina et al. [36] by the equipment Shimadzu, SPD-20A detector and LC-10AT pump detecting at $280 \mathrm{~nm}$. Samples were eluted in a Molecular Exclusion Column BioSep-Sec 2000 with an isocratic flow of $1 \mathrm{~mL} / \mathrm{min}$ and phosphate buffer $50 \mathrm{mM}$ (pH 6.8) $0.5 \%$ of SDS as mobile fase. Samples were prepared in mobile fase in a concentration of $2 \mathrm{mg} / \mathrm{mL}$. Hydrolysis percentage was determined by quantifying $\alpha$-lactalbumin in each hydrolysate with an $\alpha$-lactalbumin calibration curve.

\subsection{Antioxidant Capacity}

Antioxidant capacity was determined by two methods: ABTS and ORAC-FL, as electron transfer (ET) and hydrogen atom transfer (HAT) methods, respectively. ABTS was performed by the method described by Re et al. [37] in which antioxidant capacity is determined by measuring ABTS reagent absorbance at $734 \mathrm{~nm}$. All samples were compared with a calibration curve of trolox. Briefly, ABTS stock solution $(7 \mathrm{mM})$ with po- 
tassium persulphate $(2.45 \mathrm{mM})$ was mixed with phosphate buffer $5 \mathrm{mM}$ pH 7.4 until reaching an absorbance of 0.7 . Then, $30 \mu \mathrm{L}$ of sample was mixed in tubes with $3 \mathrm{~mL}$ of ABTS in buffer and 10 minutes later absorbance was measured in a spectrophotometer. In addition, doses-response curves were done to calculate $\mathrm{IC}_{50}$ by constructing the curve\% Inhibition vs. [Protein] ( $\mathrm{mg} / \mathrm{mL}$ ) (from 0.25 to $5 \mathrm{mg} / \mathrm{mL}$ of protein) and obtaining the logarithmic function in order to calculate the corresponding protein concentration to $50 \%$ of inhibition. Inhibition percentage is calculated according to Equation (3):

$$
\text { \%Inhibition }=\frac{A_{\text {control }}-A_{\text {antioxidant }}}{A_{\text {control }}}
$$

where $A_{\text {control }}$ is the absorbance of $3 \mathrm{~mL}$ of ABTS in buffer with $30 \mu \mathrm{L}$ of buffer and $A_{\text {antioxidant }}$ is the absorbance of $3 \mathrm{~mL}$ of ABTS in buffer with $30 \mu \mathrm{L}$ of trolox or sample.

ORAC-FL was performed as described by Ou et al. [38] modified by Dávalos et al. [39] in which a fluorescent probe (FL) is oxidized by an oxygen radical generator (AAPH) lowering its fluorescence intensity. Measurements were displayed at $485 \mathrm{~nm}$ and $520 \mathrm{~nm}$ of excitation and emission wave lengths, respectively, at $37^{\circ} \mathrm{C}$ for $104 \mathrm{mi}-$ nutes in the equipment Varioskan ${ }^{\circledast}$ Flash. Briefly, samples and reagents were prepared in phosphate buffer $75 \mathrm{mM}$ pH 7.4. Each well had a final volume of $200 \mu \mathrm{L}: 120 \mu \mathrm{L}$ of $1.17 \mathrm{mM}$ fluorescein solution (70 $\mathrm{nM}$ final concentration), $60 \mu \mathrm{L}$ of AAPH (12 mM final concentration) and $20 \mu \mathrm{L}$ of antioxidant substance (trolox or sample). All samples were prepared in duplicate and each one of the preparations was tested at least in triplicate. Equation (4) shows calculation of the area under the curve (AUC) Fluorescence vs Time:

$$
\mathrm{AUC}=1+\sum_{i=1}^{i=104} f_{i} / f_{0}
$$

where $f_{0}$ is the fluorescence at 10 minutes of incubation at $37^{\circ} \mathrm{C}$ and $f_{i}$ is the fluorescence measured every minute. Curves of Fluorescence vs Time were normalized to the curve of the blank calculating the net AUC as the difference between $\mathrm{AUC}_{\text {antioxidant (trolox or }}$

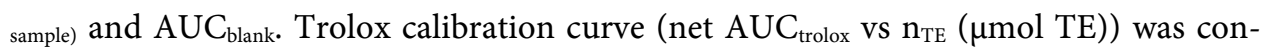
structed in order to calculate samples antioxidant capacity ( $\mu \mathrm{mol} \mathrm{TE} / \mathrm{mg}$ of protein). Besides punctual measurements, $\mathrm{IC}_{50}$ values were obtained by constructing the curve $n_{\mathrm{TE}}$ vs [Protein] (mg/mL) to obtain logarithmic function and the concentration of protein correspondent to $50 \%$ inhibition of peroxyl radicals.

\subsection{Antiglycant Activity}

Antiglycant activity was assessed using two methods: BSA-MGO and BSA-Glc.

In vitro glycation assay with BSA-MGO was determined as described by Wang et al. [28] with some modifications. Briefly, concentrations of 5 and $10 \mathrm{mM}$ (final concentration) of methylglyoxal (MGO) were mixed with $2 \mathrm{mg} / \mathrm{mL}$ BSA ( $1 \mathrm{mg} / \mathrm{mL}$ final concentration) and sufficient volume of phosphate buffer $10 \mathrm{mM} \mathrm{pH} 7.4$ with $0.02 \%$ sodium azide, in a final volume of $5 \mathrm{~mL}$. Negative control was prepared with $2.5 \mathrm{~mL}$ of BSA and $2.5 \mathrm{~mL}$ of phosphate buffer, and positive control was prepared with BSA, MGO and sufficient volume of phosphate buffer. Aminoguanidine was used as the reference sub- 
stance and it was mixed with BSA, MGO and phosphate buffer in three final concentrations: 1,4 and $8 \mathrm{mM}$. Sample 4 was tested in concentrations of 1 and $10 \mathrm{mg} / \mathrm{mL}$. All the tubes were incubated at $37^{\circ} \mathrm{C}$ for 13 days measuring fluorescence at $340 \mathrm{~nm}$ and 420 $\mathrm{nm}$ of excitation and emission wave lengths, respectively. Inhibition percentage was calculated as fallows (Equation (5)):

$$
\text { \%Inhibition }=\left(1-\frac{\text { Fluorescence with inhibitor }}{\text { Fluorescence without inhibitor }}\right) \times 100
$$

In vitro glycation assay with BSA-Glc was determined as described by Mesías et al. (25) with some modifications. Glucose was prepared in concentrations of 20 and 40 $\mathrm{mM}$ (final concentration) in a final volume of $5 \mathrm{~mL}$ mixing it with BSA ( $1 \mathrm{mg} / \mathrm{mL}$ final concentration) and sufficient volume of the same phosphate buffer as BSA-MGO model. Negative control used was the same as BSA-MGO assay and positive control was prepared with Glc, BSA and phosphate buffer. Sample tested concentrations were the same, incubation and measurement conditions were the same as well.

\subsection{Antihypertensive Activity}

Antihypertensive activity was determined as described by Cushman \& Cheung [40] modified by Kim et al. [41]. In this assay, the inhibition of angiotensin converting enzyme (ACE) was evaluated. Briefly, samples concentration of $5 \mathrm{mg} / \mathrm{mL}$ were prepared in borate buffer $0.2 \mathrm{M} \mathrm{pH} 8.3$ and agitated at $25^{\circ} \mathrm{C}, 700 \mathrm{rpm}$, for 30 minutes to solubilize them. Then, samples were centrifuged at $9.500 \mathrm{rpm}$ for 20 minutes at $20^{\circ} \mathrm{C}$. Assay buffer (borate buffer $0.2 \mathrm{M}$ and $\mathrm{NaCl} 2 \mathrm{M}, \mathrm{pH}$ 8.3) was added to the sample, mili Q water and HHL $5 \mathrm{mM}$. Eppendorf tubes were incubated at $37^{\circ} \mathrm{C}, 700 \mathrm{rpm}$, for 5 minutes, and ACE was added in cold $(0-10 \mathrm{mU})$. Same tubes were incubated at $37^{\circ} \mathrm{C}, 700 \mathrm{rpm}$, for 30 minutes and after, tubes were incubated at $90^{\circ} \mathrm{C}$ for 10 minutes. Finally, colour reagent and potassium phosphate buffer $0.2 \mathrm{M} \mathrm{pH} 8.3$ were added, samples were centrifuged at $20^{\circ} \mathrm{C}, 6000 \mathrm{rpm}$, for 10 minutes and supernatant absorbance was measured at $382 \mathrm{~nm}$. ACE inhibition percentage was calculated according to equation 6 :

$$
\% \text { ACE Inhibition }=100 \times\left[1-\left(\frac{A_{S}-A_{0 S}}{A_{\max }-A_{0 \max }}\right)\right]
$$

where $A_{\mathrm{s}}$ and $A_{0 \mathrm{~s}}$ are the absorbance of sample in ACE's presence and absence, respectively; $A_{\max }$ is the absorbance in the absence of sample and $A_{0 \max }$ is the absorbance in the absence of sample and ACE.

\subsection{Statistical Analysis.}

All the measurements were determined at least in triplicate. Results were expressed as means values \pm standard deviation. Analysis of variance (ANOVA) and Tukey test were applied to determine significant differences between values $(p<0.05)$. Statistical analysis was done using Infostat v. 2015 and Statgraphic Plus v. 5.1 programs.

\section{Results and Discussion}

\subsection{Optimization of the Hydrolysis Process}

Hydrolysis of $\alpha$-lactalbumin with Alcalase enzyme preparation on buffer phosphate so- 
lution $(\mathrm{pH} 7,100 \mathrm{mM})$ was studied as a strategy for the valorization of whey protein fractions, a by-product usually discarded by small and medium dairy enterprises. Initially, protein content and hydrophobicity were determined in the supernatants of the hydrolysates samples 1 to 7 . Sample 3 formed a gel after heating at $100^{\circ} \mathrm{C}$ for $10 \mathrm{mi}$ nutes, probably because of the reaction conditions that favoured $\alpha$-lactalbumin intermolecular interaction by disulfide bonds. For this reason, sample 3 was discarded for subsequent analysis.

It could be observed that protein content measurements tended to increase with factors time of hydrolysis and $r$ (enzyme to substrate ratio, see Table 1 ). Conversely, surface hydrophobicity decreased after $60 \mathrm{~min}$ of hydrolysis at factor $r=0.1000$.

Hydrolysis carried out by subtilisin-like enzymes (such as alcalase) might convert some hydrophobic groups to hydrophilic groups by generating two-end carbonyl and amino groups [42] [43]. Furthermore, enhanced protein hydrolysate content can be attributed to the release of small soluble peptides and new carboxylic and amine groups from aminoacids, increasing exposure of more polar and charged groups to surrounding water [44], therefore reducing hydrophobicity values.

Hydrolysis percentages determined by SE-HPLC were 0 for samples with 0 minutes of reaction as expected. Samples 5, 6 and 7 have the same reaction conditions and presented no significant differences between them $(p<0.05)$ as expected. Sample 4 had the higher hydrolysis percentage of all samples related to greater protein hydrolysis.

To continue with the characterization of hydrolysates, electrophoresis gels were made (Figure 1). As it can be observed in Figure 1, samples 1 and 2 (lanes 1 and 2, respectively) show the same bands as $\alpha$-lactalbumin (lane 8) confirming there was no hydrolysis at 0 minutes of reaction. As to samples 4, 5, 6 and 7, no band can be discriminated probably because of the extent of hydrolysis reaction (Table 1) forming small peptides which could have escaped the gel pore.

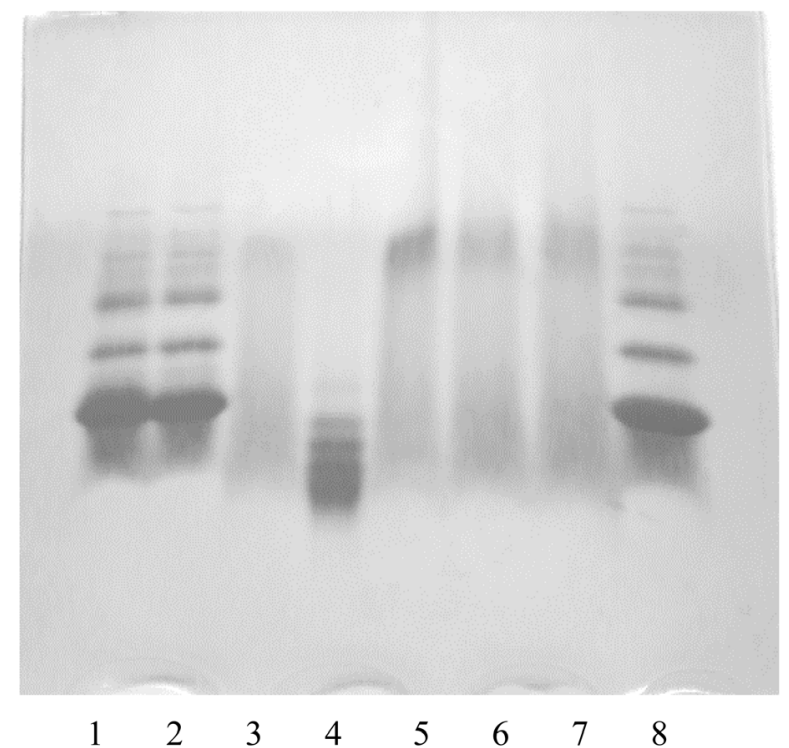

Figure 1. Electrophoresis gel of the $\alpha$-lactalbumin hydrolysates and the molecular weight marker. Lanes 1 and 2: samples 1 and 2, respectively; lane 3, 5, 6 and 7: samples 4, 5, 6 and 7, respectively; lane 4: molecular weight marker (MWM); lane 8: $\alpha$-lactalbumin. 
According to Peng et al. [45], hydrolysis percentage of whey protein isolate after 5 hours of enzymatic hydrolysis with Alcalase was of $35 \%-36 \%$, which is a little bit higher than sample 4 percentage of hydrolysis. In such study, this percentage increased in the first 3 hours reaching a plateau at 5 hours. The value of 3 hours of hydrolysis would be comparable to the one of sample 4 ( 1 hour of hydrolysis) which could be explained because of being a mix of whey proteins in contrast with $\alpha$-lactalbumin isolate, and because of different hydrolysis conditions. Adjonu et al. [3] treated whey protein isolate with chymotrypsin, pepsin and trypsin reaching lower percentage of hydrolysis. Alcalase hydrolysates appear to be more hydrolyzed than digestive enzymes, possibly because of its non-specificity [3] producing a great quantity of short peptides with bioactive properties [9] [46].

\subsection{Bioactive Properties.}

\subsubsection{Antioxidant Capacity}

The antioxidant capacity was determined by ABTS and ORAC-FL methods evaluating the relation between the two factors (enzyme: substrate ratio and time) and the antioxidant capacity. The coefficients obtained from multiple linear analyses are listed in Table 2. Both response variables (ABTS and ORAC-FL) have similar tendencies. The coefficient values show a positive effect on the factor time. The factor enzyme: substrate ratio was discarded because of showing a p-value higher than 0.01 . As to the model, in both cases $\mathrm{R}^{2}$ is near 1 so it can be concluded that the variation of the antioxidant capacity with the factors fits the model adequately $(p<0.01)$.

Figure 2 shows surface plots of the antioxidant capacity as the response variable, measured by ABTS and ORAC-FL methods, as a function of enzyme: substrate ratio $(0.0050-0.1000 \mathrm{w} / \mathrm{w})$ and time $(0-60$ minutes $)$. Both graphs show similar tendencies increasing the antioxidant capacity with time, showing a maximum with $0.1000 \mathrm{w} / \mathrm{w}$ and 60 minutes (sample 4). Sample 4 presented $1.015 \pm 0.042$ and $1.495 \pm 0.114 \mu \mathrm{mol}$ $\mathrm{TE} / \mathrm{mg}$ of protein, compared to $\alpha$-lactalbumin $0.191 \pm 0.007$ and $0.159 \pm 0.011 \mu \mathrm{mol}$ $\mathrm{TE} / \mathrm{mg}$ of protein, for ABTS and ORAC-FL antioxidant capacity, respectively. Sample 4 values of antioxidant capacity showed significant differences between the other samples, having grater antioxidant power. In addition, $\mathrm{IC}_{50}$ values were obtained for sample

Table 2. Coefficients of the Equation (1) and statistics obtained for the response surface model by multiple linear regression analysis, for ABTS and ORAC-FL response variables.

\begin{tabular}{ccc}
\hline Terms & $\begin{array}{c}\text { ABTS value } \\
(\mu \mathrm{mol} \text { Trolox } / \mathrm{mg} \text { protein })\end{array}$ & $\begin{array}{c}\text { ORAC-FL value } \\
(\mu \mathrm{mol} \text { Trolox } / \mathrm{mg} \text { protein })\end{array}$ \\
\hline Constant & 0.2271 & 0.4662 \\
Enzyme: substrate ratio $(\mathrm{w} / \mathrm{w})(r)$ & - & - \\
Time (minutes) $(t)$ & 0.0350 & 0.0380 \\
$r \times t$ & -0.2187 & -0.2090 \\
$R^{2}$ & 0.989308 & 0.970826 \\
$p$ & 0.0000 & 0.0000 \\
\hline
\end{tabular}

$r$. enzyme: substrate ratio; $t$ : time; $R^{2}$ : determination coefficient; $p$ : $p$-value for the unfit of the model (coefficients were $p<0.01)$. 


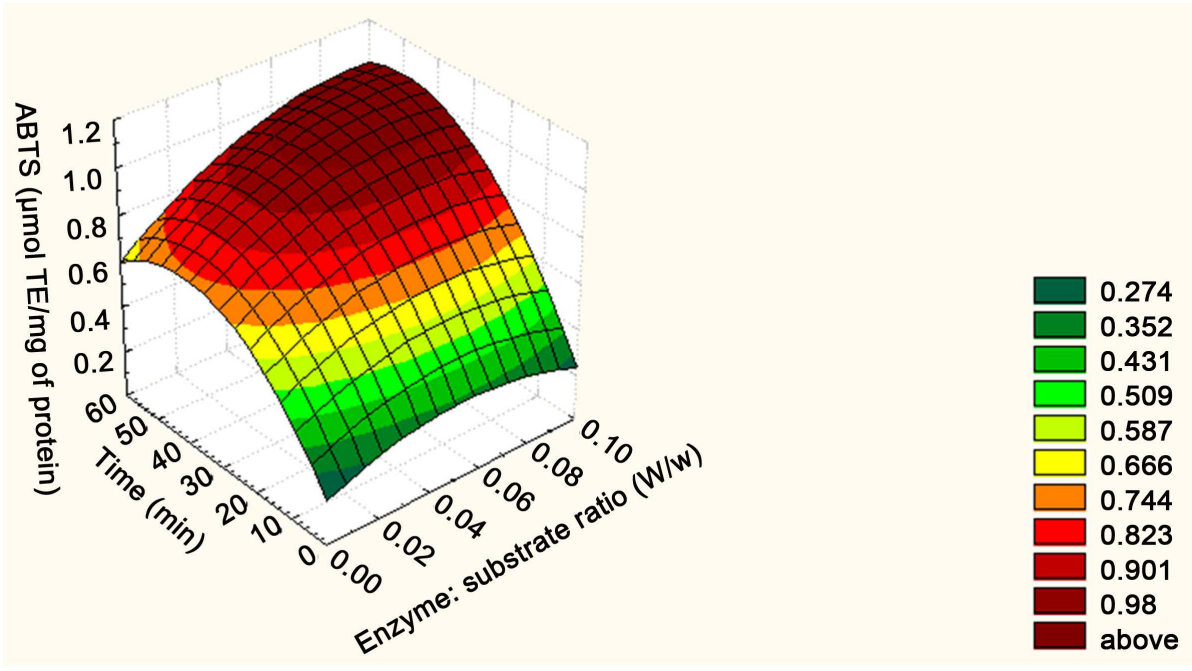

(a)
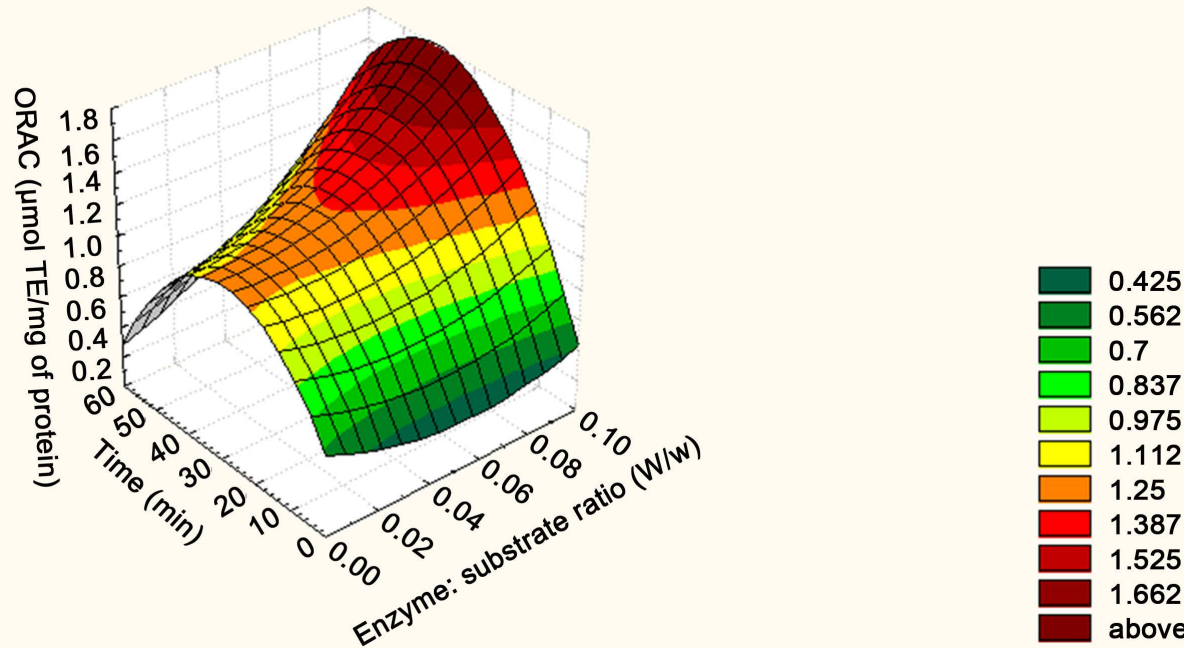

(b)

Figure 2. Surface plot of antioxidant activity as the response variable, determined by (a) ABTS and (b) ORAC-FL methods as a function of time (minutes) and enzyme: substrate ratio ( $w$ of enzyme/w of $\alpha$-lactalbumin).

$4(1.018 \pm 0.026$ and $0.152 \pm 0.010 \mathrm{mg} / \mathrm{mL}$ of protein for ABTS and ORAC-FL, respectively) and $\alpha$-lactalbumin (15.732 \pm 0.256 and $0.223 \pm 0.014 \mathrm{mg} / \mathrm{mL}$ of protein for ABTS and ORAC-FL, respectively). These values confirm sample 4 has a higher antioxidant capacity stating it increases with the percentage of hydrolysis [46] confirmed by SE-HPLC (Section 3.1). This suggests that short peptides liberated during hydrolysis are responsible for the antioxidant capacity" [13] being liberated during hydrolysis. These values are similar to those of other enzymes using longer time of reaction [3] [13], stablishing Alcalase is more efficient than other enzymes, being possible to obtain powerful antioxidant hydrolysates in less time of reaction.

\subsubsection{ACE Inhibition Activity}

As to antihypertensive properties measured in vitro, sample 4 presented $30 \%$ of ACE 
inhibition with respect to Captopril (data not shown). These low inhibition percentage could be explained by the fact that hydrolysis was not enough to release shorter peptides which are the responsible ones for ACE inhibitory activity [15]. Our recent work is focused on studying the effect of digestion on sample 4 by in vitro simulation which could demonstrate better ACE-inhibitory activity because of enhancing peptide hydrolysis. Hernández-Ledesma et al. [15] already studied the effect of digestion on infant formula demonstrating hydrolysis can enhance ACE-inhibitory activity. Separation of sample 4 lower molecular weight peptides could also enhance this activity applying ultrafiltration for the concentration of these peptides [9].

\subsubsection{Antiglycant Activity}

In contrast, no antiglycant in vitro properties were found in sample 4. Moreover, sample 4 (concentration $1 \mathrm{mg} / \mathrm{mL}$ of dry mass) demonstrated to favour protein glycation (AGEs formation) in time leveling with positive control for MGO (5 and $10 \mathrm{mM}$ )-BSA and Glc-BSA models (data not shown). AG concentrations of 4 and $8 \mathrm{mM}$ showed complete glycation inhibition (AGEs formation inhibition) for both concentrations of MGO and for Glc during the time of the study. For AG concentration of $1 \mathrm{mM}$, inhibition of AGEs formation was complete only for Glc model and for MGO was complete until day 6. These results infer MGO is more reactive with sample 4 than Glc, being in accordance with previous researches involving plasma [47]. MGO is more reactive than Glc because of being a dicarbonyl (Maillard reaction intermediate) [21] [48].

Regarding all the results, sample 4 could be labeled as a powerful antioxidant ingredient for the prevention of chronic diseases related to oxidative stress.

\section{Conclusion}

The effect of different enzyme: substrate ratio and time conditions on antioxidant activity of $\alpha$-lactalbumin hydrolyzed with Alcalase was evaluated using response surface methodology, finding greater antioxidant activity in the hydrolysate with $0.1 \% \mathrm{w} / \mathrm{w}$ for enzyme: substrate ratio and 60 minutes for time of reaction (sample 4). The methodology demonstrated time had a positive influence over antioxidant activity because of more hydrolysis (release of shorter peptides), confirmed by SE-HPLC. A pool of short peptides in sample 4 could be responsible for these high antioxidant activities. In contrast, low ACE-inhibitory activity was found in sample 4 probably because of not enough hydrolysis in order to release the tripeptides responsible for these activities, but promising activity could be found after in vivo digestion. As to antiglycant activity, sample 4 showed to favoured AGEs formation with MGO and Glc, not being able to be used as antidiabetic ingredient.

\section{Acknowledgements}

The research that gives rise to the results presented in this publication received funding from the National Agency for Research and Innovation under the code POS_NAC_ 2013_1_11655. Theauthorswouldlike to acknowledge Paula Aphalo and María Cristina Añón of the Centro de Investigación y Desarrollo en Criotecnología de Alimentos (CIDCA) (CCT La Plata, CONICET), Facultad de Ciencias Exactas, Universidad 
Nacional de La Plata (UNLP), 47 y 116 (1900), La Plata, Argentina for their technical assistance and Laboratorio de Fisicoquímica Biológica (Instituto Química Biológica, Facultad de Ciencias, UdelaR) forthe loan of equipment.

\section{References}

[1] Adjonu, R., Doran, G., Torley, P. and Agboola, S. (2014) Whey Protein Peptides as Components of Nanoemulsions: A Review of Emulsifying and Biological Functionalities. Journal of Food Engineering, 122, 15-27. https://doi.org/10.1016/j.jfoodeng.2013.08.034

[2] Madureira, A.R., Pereira, C.I., Gomes, A.M.P., Pintado, M.E. and Xavier Malcata, F. (2007) Bovine Whey Proteins-Overview on Their Main Biological Properties. Food Research International, 40, 1197-1211. https://doi.org/10.1016/j.foodres.2007.07.005

[3] Adjonu, R., Doran, G., Torley, P. and Agboola, S. (2013) Screening of Whey Protein Isolate Hydrolysates for Their Dual Functionality: Influence of Heat Pre-Treatment and Enzyme Specificity. Food Chemistry, 136, 1435-1443. https://doi.org/10.1016/j.foodchem.2012.09.053

[4] Tavares, T.G., Amorim, M., Gomes, D., Pintado, M.E., Pereira, C.D. and Malcata, F.X. (2012) Manufacture of Bioactive Peptide-Rich Concentrates from Whey: Characterization of Pilot Process. Journal of Food Engineering, 110, 547-552. https://doi.org/10.1016/j.jfoodeng.2012.01.009

[5] Demarest, S.J., Boice, J.A, Fairman, R. and Raleigh, D.P. (1999) Defining the Core Structure of the Alpha-Lactalbumin Molten Globule State. Journal of Molecular Biology, 294, $213-$ 221. https://doi.org/10.1006/jmbi.1999.3228

[6] Lam, R.S.H. and Nickerson, M.T. (2014) The Effect of $\mathrm{pH}$ and Temperature Pre-Treatments on the Physicochemical and Emulsifying Properties of Whey Protein Isolate. LWT-Food Science and Technology, 173, 163-170.

[7] Permyakov, E.A. and Berliner, L.J. (2000) Alpha-Lactalbumin: Structure and Function. FEBS Letters, 473, 269-274. https://doi.org/10.1016/S0014-5793(00)01546-5

[8] Gauthier, S.F. and Pouliot, Y. (2003) Functional and Biological Properties of Peptides Obtained by Enzymatic Hydrolysis of Whey Proteins. Journal of Dairy Science, 86, E78-E87. https://doi.org/10.3168/jds.S0022-0302(03)74041-7

[9] Korhonen, H. and Pihlanto, A. (2006) Bioactive Peptides: Production and Functionality. International Dairy Journal, 16, 945-960. https://doi.org/10.1016/j.idairyj.2005.10.012

[10] Prior, R.L. (2014) Oxygen Radical Absorbance Capacity (ORAC): New Horizons in Relating Dietary Antioxidants/Bioactives and Health Benefits. Journal of Functional Foods, 18, 797810 .

[11] Halliwell, B. and Gutteridge, J.M. (1984) Oxygen Toxicity, Oxygen Radicals, Transition Metals and Disease.The Biochemical Journal, 219, 1-14. https://doi.org/10.1042/bj2190001

[12] Tironi, V.A. and Añón, M.C. (2010) Amaranth Proteins as a Source of Antioxidant Peptides: Effect of Proteolysis. Food Research International, 43, 315-322.

https://doi.org/10.1016/j.foodres.2009.10.001

[13] Contreras, M.D.M., Hernández-Ledesma, B., Amigo, L., Martín-Álvarez, P.J. and Recio, I. (2011) Production of Antioxidant Hydrolyzates from a Whey Protein Concentrate with Thermolysin: Optimization by Response Surface Methodology. LWT-Food Science and Technology, 44, 9-15. https://doi.org/10.1016/j.lwt.2010.06.017

[14] Sadat, L., Cakir-Kiefer, C., N’Negue, M.-A., Gaillard, J.-L., Girardet, J.-M. and Miclo, L. (2011) Isolation and Identification of Antioxidative Peptides from Bovine $\alpha$-Lactalbumin. International Dairy Journal, 21, 214-221. https://doi.org/10.1016/j.idairyj.2010.11.011

[15] Hernández-Ledesma, B., Amigo, L., Ramos, M. and Recio, I. (2004) Release of Angiotensin 
Converting Enzyme-Inhibitory Peptides by Simulated Gastrointestinal Digestion of Infant Formulas .International Dairy Journal, 14, 889-898. https://doi.org/10.1016/j.idairyj.2004.02.011

[16] Ahmed, N. (2005) Advanced Glycation Endproducts-Role in Pathology of Diabetic Complications. Diabetes Research and Clinical Practice, 67, 3-21. https://doi.org/10.1016/j.diabres.2004.09.004

[17] Surya, S., Salam, A.D., Tomy, D.V., Carla, B., Kumar, R.A. and Sunil, C. (2014) Diabetes Mellitus and Medicinal Plants-A Review. Asian Pacific Journal of Tropical Disease, 4, 337347. https://doi.org/10.1016/S2222-1808(14)60585-5

[18] Arumugam, G., Manjula, P. and Paari, N. (2013) A Review: Anti Diabetic Medicinal Plants Used for Diabetes Mellitus. Journal of Acute Disease, 2, 196-200. https://doi.org/10.1016/S2221-6189(13)60126-2

[19] Ahmed, N and Thornalley, P.J. (2007) Advanced Glycation Endproducts: What Is Their Relevance to Diabetic Complications? Diabetes, Obesity and Metabolism, 9, 233-245. https://doi.org/10.1111/j.1463-1326.2006.00595.x

[20] Szawara-Nowak, D., Koutsidis, G., Wiczkowski, W. and Zieliński, H. (2014) Evaluation of the in Vitro Inhibitory Effects of Buckwheat Enhanced Wheat Bread Extracts on the Formation of Advanced Glycation End-Products (AGEs). LWT-Food Science and Technolo$g y$, 58, 327-334. https://doi.org/10.1016/j.lwt.2013.03.005

[21] Luevano-Contreras, C. and Chapman-Novakofski, K. (2010) Dietary Advanced Glycation End Products and Aging. Nutrients, 2, 1247-126522. https://doi.org/10.3390/nu2121247

[22] Peyroux, J. and Sternberg, M. (2006) Advanced Glycation Endproducts (AGEs): Pharmacological Inhibition in Diabetes. Pathologie Biologie, 54, 405-419. https://doi.org/10.1016/j.patbio.2006.07.006

[23] Spotti, M.J., Martinez, M.J., Pilosof, A.M.R., Candioti, M., Rubiolo, A.C. and Carrara, C.R. (2014) Influence of Maillard Conjugation on Structural Characteristics and Rheological Properties of Whey Protein/Dextran Systems. Food Hydrocolloids, 39, 223-230. https://doi.org/10.1016/j.foodhyd.2014.01.014

[24] Lunceford, N. and Gugliucci, A. (2005) Ilex Paraguariensis Extracts Inhibit AGE Formation More Efficiently than Green Tea. Fitoterapia, 76, 419-427. https://doi.org/10.1016/j.fitote.2005.03.021

[25] Mesías, M., Navarro, M., Martínez-Saez, N., Ullate, M., del Castillo, M.D. and Morales, F.J. (2014) Antiglycative and Carbonyl Trapping Properties of the Water Soluble Fraction of Coffee Silverskin. Food Research International, 62, 1120-1126. https://doi.org/10.1016/j.foodres.2014.05.058

[26] Uribarri, J., Dolores, M., Castillo, D., Pia, M., Maza, D.L., Filip, R., Gugliucci, A., Luevano-Contreras, C., Macias-Cervantes, M.H., Markowicz Bastos, D.H., Medrano, A., Menini, T., Portero-Otin, M., Rojas, A., Sampaio, G.R., Wrobel, K., Wrobel, K. and GaraySevilla, M.E. (2015) DietaryAGEs and Their Role in Health and Disease. Advances in Nutrition, 6, 461-473.

[27] Fritz, M., Vecchi, B., Rinaldi, G. and Añón, M.C. (2011) Amaranth Seed Protein Hydrolysates Have in Vivo and in Vitro Antihypertensive Activity. Food Chemistry, 126, 878884. https://doi.org/10.1016/j.foodchem.2010.11.065

[28] Wang, X., Wang, L., Cheng, X., Zhou, J., Tang, X. and Mao, X.Y. (2012) Hypertension-Attenuating Effect of Whey Protein Hydrolysate on Spontaneously Hypertensive Rats. Food Chemistry, 134, 122-126. https://doi.org/10.1016/j.foodchem.2012.02.074

[29] Murray, B.A. and FitzGerald, R.J. (2007) Angiotensin Converting Enzyme Inhibitory Peptides Derived from Food Proteins: Biochemistry, Bioactivity and Production. Current Pharmaceutical Design, 13, 773-791. https://doi.org/10.2174/138161207780363068 
[30] O’Loughlin, I.B., Murray, B.A., Brodkorb, A., FitzGerald, R.J. and Kelly, P.M. (2014) Production of Whey Protein Isolate Hydrolysate Fractions with Enriched ACE-Inhibitory Activity. International Dairy Journal, 38, 101-103. https://doi.org/10.1016/j.idairyj.2013.12.008

[31] Box, G.E.P., Hunter, J.S. and Hunter, W.G. (1978) Statistics for Experimenters. An Introduction to Design, Data Analysis, and Model Building. John Wiley \&Sons, New York.

[32] Lowry, O., Rosebrough, N., Farr, A. and Randall, R. (1951) Protein Measurement with the Folin-Phenol Reagent. Journal of Biological Chemistry, 193, 265-275.

[33] Hayakawa, S. and Nakai, S. (1985) Contribution of Hydrophobicity, Net Charge and Sulfhydryl Groups to Thermal Properties of Ovalbumin. Canadian Institute of Food Science and Technology, 18, 290-295. https://doi.org/10.1016/S0315-5463(85)71960-8

[34] Kato, A. and Nakai, S. (1980) Hydrophobicity Determined by Fluorescence Probe Method and Its Correlations with Surface Properties of Proteins. Biochemicaet Biophysica Acta, 624, 13-20. https://doi.org/10.1016/0005-2795(80)90220-2

[35] Schägger, H. and von Jagow, G. (1987) Tricine-Sodium Dodecyl Sulfate-Polyacrylamide Gel Electrophoresis for the Separation of Proteins in the Range from 1 to $100 \mathrm{kDa}$. Analytical Biochemistry, 166, 368-379. https://doi.org/10.1016/0003-2697(87)90587-2

[36] Molina Ortiz, S.E. (1997) Modificación enzimática de propiedades funcionales de aislados proteicos de soja. Tesis Doctoral, Universidad Nacional de la Plata, Facultad de Ciencias Exactas, Departamento de Química.

[37] Re, R., Pellegrini, N., Proteggente, A., Pannala, A., Yang, M. and Rice-Evans, C. (1999) Antioxidant Activity Applying an Improved ABTS Radical Cation Decolorization Assay. Free Radical Biology \& Medicine, 26, 1231-1237. https://doi.org/10.1016/S0891-5849(98)00315-3

[38] Ou, B., Hampsch-woodill, M. and Prior, R. (2001) Development and Validation of an Improved Absorbance Capacity Assay Ussing Fluorescein as the Fluorescent. Journal of Agriculture and Food Chemistry, 49, 4619-4626. https://doi.org/10.1021/jf010586o

[39] Dávalos, A., Bartolomé, B. and Gómez-Cordovés, C. (2005) Antioxidant Properties of Commercial Grape Juices and Vinegars. Food Chemistry, 93, 325-330. https://doi.org/10.1016/j.foodchem.2004.09.030

[40] Cushman, D.W. and Cheung, H.S. (1971) Spectrophotometric Assay and Properties of the Angiotensin-Converting Enzyme of Rabbit Lung. Biochemical Pharmacology, 20, 16371648. https://doi.org/10.1016/0006-2952(71)90292-9

[41] Kim, Y., Yoon, S., Yu, D., Lönnerdal, B. and Cheung, B. (1999) Novel Angiotensin-IConverting Enzyme Inhibitory Peptides Derived from Recombinant Human as1-Casein Expressed in Escherichia coli. Journal of Dairy Research, 66, 431-439. https://doi.org/10.1017/S0022029999003556

[42] Betty, M., Awuor, O.L., Kirwa, M.E. and Jakim, M.F. (2014) Antioxidative and Functional Properties of Rastrineobolaargentea (Dagaa) Fish Protein Hydrolysate. Discourse Journal of Agriculture and Food Science, 2, 180-189.

[43] Halim, N.R.A., Yusof, H.M. and Sarbon, N.M. (2016) Functional and Bioactive Properties of Fish Protein Hydrolysates and Peptides: A Comprehensive Review. Trends in Food Science and Technology, 51, 24-33. https://doi.org/10.1016/j.tifs.2016.02.007

[44] Jemil, I., Jridi, M., Nasri, R., Ktari, N. Salem, R.B.S., Mehiri, M., et al. (2014) Functional, Antioxidant and Antibacterial Properties of Protein Hydrolysates Prepared from Fish Meat Fermented by Bacillus subtilis A26. Process Biochemistry, 49, 963-972. https://doi.org/10.1016/j.procbio.2014.03.004

[45] Peng, X., Xiong, Y.L. and Kong, B. (2009) Antioxidant Activity of Peptide Fractions from Whey Protein Hydrolysates as Measured by Electron Spin Resonance. Food Chemistry, 113, 196-201. https://doi.org/10.1016/j.foodchem.2008.07.068

[46] Saadi, S., Saari, N., Anwar, F., Abdul Hamid, A. and Ghazali, H.M. (2015) Recent Advances 
in Food Biopeptides: Production, Biological Functionalities and Therapeutic Applications. Biotechnology Advances, 33, 80-116. https://doi.org/10.1016/j.biotechadv.2014.12.003

[47] Gugliucci, A. (2003) A Practical Method to Study Functional Impairment of Proteins by Glycation and Effects of Inhibitors Using Current Coagulation/Fibrinolysis Reagent Kits. Clinical Biochemistry, 36, 155-158. https://doi.org/10.1016/s0009-9120(02)00442-3

[48] Gugliucci, A. (2000) Glicación de proteínas: Rol protagónico de la hiperglicemia en las complicaciones crónicas de la diabetes mellitus. Revista de Medicina de Uruguay, 16, 58-75.

Submit or recommend next manuscript to SCIRP and we will provide best service for you:

Accepting pre-submission inquiries through Email, Facebook, LinkedIn, Twitter, etc. A wide selection of journals (inclusive of 9 subjects, more than 200 journals)

Providing 24-hour high-quality service

User-friendly online submission system

Fair and swift peer-review system

Efficient typesetting and proofreading procedure

Display of the result of downloads and visits, as well as the number of cited articles Maximum dissemination of your research work

Submit your manuscript at: http://papersubmission.scirp.org/

Or contact fns@scirp.org 